\title{
제 934차 OECD DAC 정례회의
}

\section{I. 회의개요}

표제회의가 2011년 6월 30일 파리 OECD 본부에서 OECD 개발협력국 주최로 Brian Atwood DAC 의장, 당관 정진규 참사관을 비롯한 회원국 DAC 대표, 사무국 Jon Lomoy 국장, Stephen Groff 부 국장 등이 참석한 가운데 개최 됨.

\section{II. 주요내용}

- 사무국은 $\mathrm{OECD}$ 의 3 번째 다자원조보고서 초안을 회람하면서 전체적 내용을 간략히 설명한 바, 프랑스, 스위스, 벨기에 등은 동보고서는 현재 다자기구의 운영의 문제점을 적절히 제시하고 있 으나 실제 다자기구의 분절화(fragmentation)문제 개선효과는 거의 없다고 지적하면서 각 다자 기구의 효과성을 제고하는 전략이 제시되어야 한다는 점 강조 함.

- 금번 3차 다자원조보고서는 다자기구의 원조보고 각 공여국의 다자기구 정책방향에 초점을 두고 있음. 특히 DAC 회원국의 다자기구 지원정책에도 중점을 두고 있음. 전반적 증가추세이며 2099 년 사상최대 기록 함. 다자개발원조에 있어서 DAC회원국 이외의 국가(BRICs를 포함한 신흥국) 의 비중이 지속적으로 증가하고 있음.

- 미국은 다자원조보고서 발간을 통해 DAC과 Non DAC 공여국(기관)에 대해 기준(reference points) 을 제시하여야 할 것이라고 하면서 개별 국가 내에서 개발원조와 관련되어 있는 부처들이 동 보 고서를 적극적으로 참고하여 다자기구의 효과성 제고에 기여하는 것이 중요하다고 언급 함.

- 세계은행은 개발 사업에 대한 Performance evaluation, sharing information은 은행의 당연한 업무라고 강조하고 세계은행 웹사이트에서도 많은 자료와 정보들을 다운로드 할 수 있고 많은 공여국 및 수원국과 관련된 자료들이 있으므로 이를 활용해 줄 것을 요청 함.

- 우리 측은 다자원보고서 발간의 메인 메시지는 다자기구의 효과성을 실질적으로 제고하는 것이 라는 점을 지적. 부산세계개발원조총회(HLF-4)에서 다룰 전체적인 원조/개발 효과성 논의에 동 보고서의 핵심내용이 적절히 반영되어야 할 것이라고 언급 함.

- 사무국은 $\mathrm{OECD}$ 개발전략(각료이사회 합의사항)에 대해 설명함. $\mathrm{OECD}$ 개발전략 관련 우선순위 분야, 선정기준, 개발정책정합성(PCD), 파리선언/아크라행동계획의 역할, $\mathrm{DAC}$ 의 역할 등을 기 여분야로 제시함.

- 대부분의 회원국들은 DAC의 OECD 개발전략에 대한 기여가 핵심적 위치를 차지해야 한다는데 동의를 표시하면서도 $\mathrm{DAC}$ 과 개발센터 $(\mathrm{DC})$ 간 보다 명확한 역할분담이 이루어져야 할 것인 바, 양 기관의 기여분야와 기여내용에 관한 보다 실질적인 협의와 조정이 필요하다고 언급 함. 